\title{
電気集じん器内のイオン風一シュリーレン 法による実験的考察一
}

山口大学足立宜良

\section{1. まえがき}

コロナ放電電界において，発生した多量のイオンが 電界の作用力で移動する際に中性ガス分子に運動量を 分つことによって中性ガス分子も移動する。こ机らの 移動は一種の風であって，イオン風(あるいは電気風， コロナ風) と呼げれる。風问は放電電極の極性に関傢

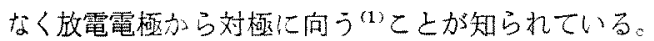

電気集じん器 (以下，EP と略記する) 内に発生す るイオン風の挙執について古くから関心が持たれ， Deutsch 氏 ${ }^{(2)}$ は針対平板電極において鎮端の直下を中 心とするリング状のダストフィギュアがイオン風によ

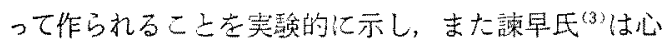
線対平板電極儿款引る電極面上のイオン圆速分有（傾 斜マノメータにて测定) とコロナ電流密度分有の関俰 を明らかにしている，たのほかにイオン風によって実 用 $\mathrm{EP}$ 内の葷電粒子が復雑な運動をするのであるうこ とは推測 ${ }^{(4)} さ$ 机ている。しかし，現在まで実用 EP D コロナ放電加行な⿰力口加平均電界強度 $(4 \sim 6 \mathrm{kV} / \mathrm{cm})^{(5)}$ において，両電極間の空間に戈けるイオン風の举動に ついて観察した報告は見あたらない。また，イオン風 によるダストの集じん過程ならびに策じん效率に与至 る影響についてはじゅうぶん明らかにされていない。

筆者は多針電極対金䋨電極に和いて，平均電界強度 $5.7 \mathrm{kV} / \mathrm{cm}$ ではイオン風速が $2.2 \mathrm{~m} / \mathrm{s}^{(6)}$ 程度であるこ 亡之，一般に実用 EP の処理ガス速度が $2.0 \mathrm{~m} / \mathrm{s}$ 义 下(7)であることから，EP 内におけるダストの補集効 果にイオン風が与える影響は非常に大きいと考える。 ここで，模擬 EP を試作して，ダストおよびがス流の

Ionic Wind in the Electrostatic Precipitator-Experimental Treatment by the Schlieren Method. By T. ADACHI, Member (Faculty of Engineering, University of Yamaguchi).

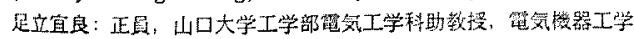
盐眥
ない大気中において雨電極間に生じるイオン風の挙動 をシュリーレン法によって観察した。さらに，サーミ

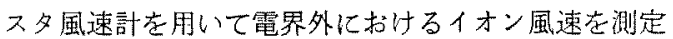
した。本論文はこれらのイオン風の挙動についての奏 垩的考察の報告で古る。

実験は大気中で行ない，そのふ九い気の条件は，温 度 $20 \sim 29^{\circ} \mathrm{C}$, 湿度 $60 \sim 80 \%$, 気圧 $999 \sim 1,020 \mathrm{mb}$ あった。

\section{2. 実験装置の概要}

第 1 図传実験回路，第 2 図汇電極構造の概要示す。 を第 1 図において $S V$ は静電電生計 $(20 \mathrm{kV}) ， A_{1}$ は 唡流計 (感度 $1.1 \times 10^{-7} \mathrm{~A}$ ), $A_{2}$ 犆流電流計 $(10 \mathrm{~A})$, 点線内はコロナ放電電極装置で, 放電線と平板電極か ら構成され，EP の電極装置を模擬したものである。 $B, R, A_{2}$ 老含む閉回路はシュリーレン法でのイオン 風の観察を容易化するための放電電極加熱用の付加回 路であって大地と絶縁されている。

第 1 図の点線内の模擬 EP は第 2 図の電極 $a-b, a-$ $c$ ならびに $d-b$ の組合せで構成し，これらについて 実験を行なった。第 2 図の電極寸法はシュリーレン装 置の凹面鏡の直径 $(325 \mathrm{~mm})$ に上って制限され，（a）

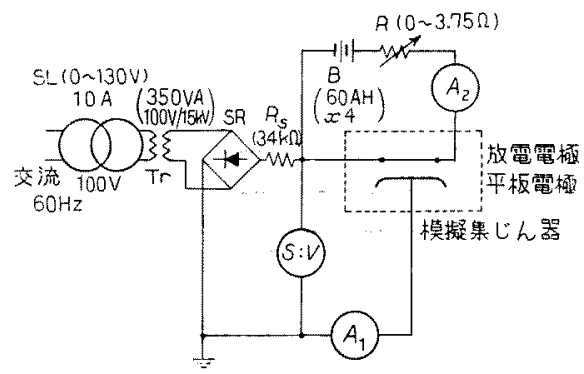

第 1 図 実験回路の概要

Fig. 1. Schematic diagram of experimental circuit. 


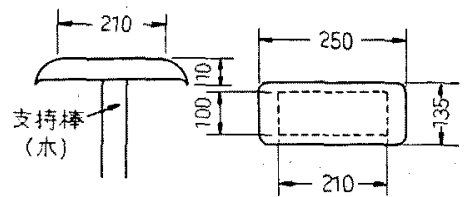

(a) 严板電極

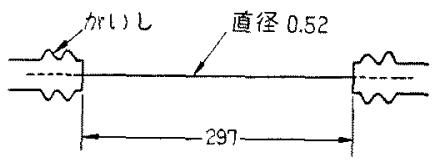

(b) 绿電極

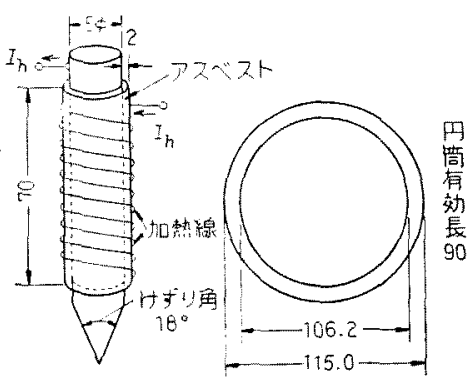

(c) 到整柾

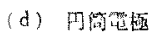

第 2 四電極構造 (单位: $\mathrm{mm}$, 材質: $\mathrm{Fe}$ )

Fig. 2. Detail of electrode.

ならこにに(d)图，は端効果対策を施された集じん電極 である。(b)图は加熱と冷却効果による線の伸縮なら びに線の振動防止をか放て一端をスプリング（張力 4 $\mathrm{kg}$ 重)で支持された線電極を示す。（c）図は石綿で 絶縁して加熱線を施した針電極である。

シュリーレン法としては平行光線中での現象を観察 できる2面対问法を用い，装圈概略を第 3 図に示す。 図中の平行光線頜域にあたる試料配置場所 $S$ には第 1 図に点線で示した模擬 $\mathrm{EP}$ をおいて，P点において イオン風の举動観察および写真撮影を行なった。撮 影，現像条件は使用フィルムの感度 ASA 200, 露出 時間 $1 / 500$, 総り開放（ $F=5.6)$ で暗室にて撮影し，2 倍に增感現像を行なった。

シュリーレン法は光の屈折を利用して空気密㞗のわ

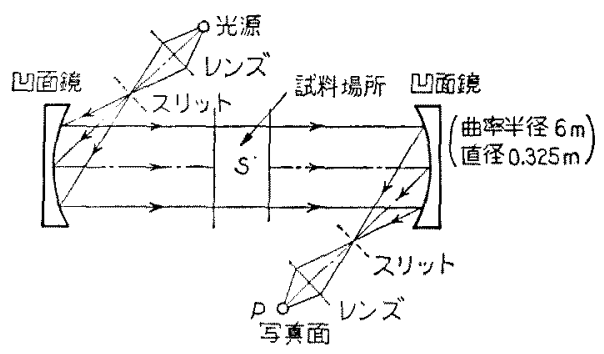

第 3 目 シュリーレン装置の概要

Fig. 3. Schematic diagram of schlieren apparatus.
ずかの違い䙷い出す方法なので，大気圧のもとで第 3 図のS の場所でコロナ放電を生じさせても，それ に伴なう気流の乱机 (イオン風) を観察することは困 難である。そこで放電電極目体を電流で加熱し，その 周囲の空気を温気に対して空気密度差を与えるて とでての目的を達する。この方法ではイオン風の挙動 の全貌をとらえることはできないが，概略の傾向を観 察することができる。模擬 $\mathrm{EP}$ 全体は，上下開放で平 行光線が遇過するところにガラス空老設けたボックス に入れて，外部の空気の流動によってイオン風が乱さ れないようにくふうされている。

第 2 困 (b) の放電線径 $(0.52 \mathrm{~mm})$ ならびに加熱電 流 $\left(I_{h}=5 \mathrm{~A}\right)$ 仕放笔線の断線, 振 動, コロ+電流, 電 源電壬，イオン風の学動の観察しやすささな゙を考慮し て定められたもので，放電線有効長におけるヒ一タに よる発熱量は 33Wである。また，第2罒の(c), (d) 電極の場合屯同様にして定数は定方られたすのであ る。

一例として第 2 図の (a )-(c) 電極の組合せに损け る放電特性老第 4 図䎲示す。両電極間距離 $D=20 \mathrm{~mm}$ としたのは印加電玨之実用 EP における平均電界強 度 ${ }^{(5)}$ 考慮して定めた。放電線を加熱した場合，コ口 十電流が著しく增加しコロナ開始電圧 (計算 ${ }^{\left({ }^{2}\right)}$ による $I_{h}=0 \mathrm{~A}$ の場合の本実験条件でコロナ開始実効電生は $7.93 \mathrm{kV})$ が著しく低下するととはすで郝告 ${ }^{(9)}$ され ており，装置は異なるが，本実験であ同じ傾向を示し ている。また, 放電線加熱電流 $I_{h}=5 \mathrm{~A}$ に求いて, 印加 電圧 $E=0 \mathrm{kV}$ では放電線は赤熱 (光高温計で $740^{\circ} \mathrm{C}$ ) されているが，印加電珃を上昇する之発生したイオン 風の風速が增加し，これによる冷却作用でだんだんし 暗赤色になり，放電特性も $I_{h}=0 \mathrm{~A}$ の特性に近ずく傾 向を示す。

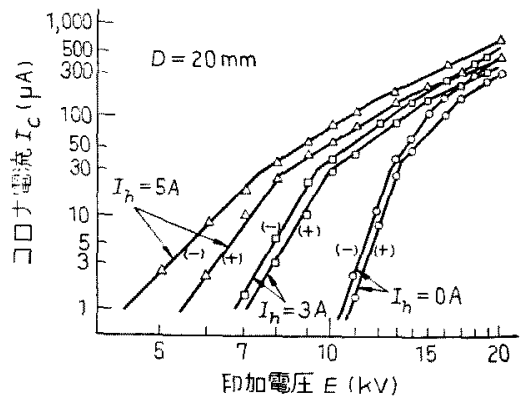

第 4 図 線対平板電極の故電特性

Fig. 4. Discharge characteristics of wire vs. plate electrode. 


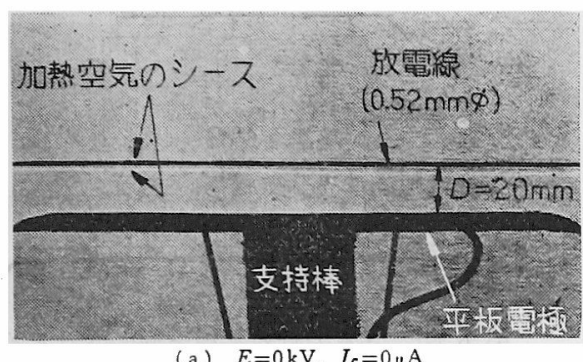

(a) $E=0 \mathrm{kV}, \quad I_{c}=0 \mu \mathrm{A}$

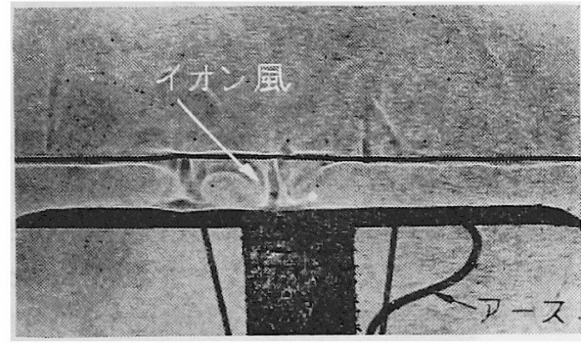

(b) $E=5.8 \mathrm{kV}, \quad I_{c}=5.8 \mu \mathrm{A}$

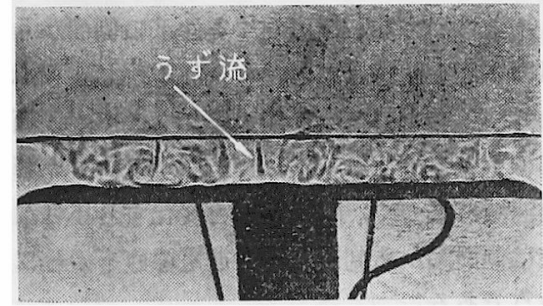

(c) $E=8.0 \mathrm{kV}, I_{c}=33.0 \mu \mathrm{A}$

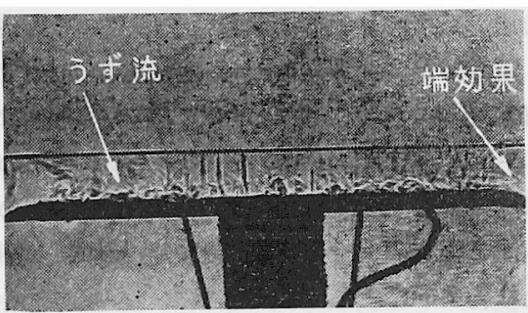

(d) $E=12.0 \mathrm{kV}, I_{c}=152 \mu \mathrm{A}$

第 5 図 線対平板電極における負性イオン風のシュリーレン写真

Fig. 5. Schlieren photographs of negative ionic wind for wire vs. plate electrode.

\section{3. シュリーレン法によるイオン風の現象観} 察と考察

〈3.1〉放電線対平板電極の場合のイオン風放 電電極の極性にはほとんど関係なくイオン風は放電電 極から対極に向って吹くわけであるが, 正性コロナ放 電または負性コロナ放電に伴って発生するイオン風を 区別して，正性イオン風または負性イオン風と呼ぶこ とにする。

第 5 図は両電極間距離 $D=20 \mathrm{~mm}$, 加熱電流 $I_{h}=$ 5A における負性イオン風のシュリーレン写真であ る。(a)図は印加電圧 $E=0 \mathrm{kV}$ の場合で, 放電線の 周囲の空気は加熱電流で温められて鞘状になるわけで 同図においては層状になって見える。（b)図はコロナ 電流が流れ始めた部分コロナ領域で，若千イオン風が 発生して気流の乱れが観察される。

(c) 図 $(4 \mathrm{kV} / \mathrm{cm}, 0.16 \mathrm{~mA} / \mathrm{m})$ は EP の実用的電界 強度ならびにコロナ電流密度に相当する全面コロナ放 電の領域で，イオン風はコロナ輝点から直線的に伸展 しておりその中間域に小さなうず流が複雑に発生して いる。放電線上から一様にコロナ放電が行なわれず, 多数のコロナ輝点（図中に直線状のイオン風が発生し ている点) が散在するのは， $\gamma$ 作用（電子放出）の大 きい箇所に自分から放電が制御集中(10) するからであ る。したがって，イオン風がうず状に発生するのは, コロナ輝点に沿って発生する個々のイオン風相互の干 渉結果によるあのと考えられる。また，コロナ輝点の
発生と消滅がくり返されるので，うず流現象は時々刻 々と変化するのが観察される。

(d)図はコロナ輝点が密になった比較的安定した放 電状態で，イオン風速が大になるから冷却効果が増大 して放電線はほとんど赤味がない。したがって, 実際 に発生している気流の乱れより屯微弱にしか観察でき ないが, 非常に小さなうず流が多数発生していると推 測される。

放電線と集じん電極の上下関係位置を逆にした場合 ならびにそれぞれを垂直にした場合でも，コロナ電流 が $30 \mu \mathrm{A}$ (第 4 図参照) 以上になると同様の現象が観 察される。また，二つの平行板電極の中央に放電線を 置いた場合においては, 前述の現象とほとんど同じで あった。さらに，これらの実験で正コロナ電流と負コ ロナ電流が等しい場合 $(30 \mu \mathrm{A}$ 以上) にはほとんど現 象に差がみられない。

時間とともに変化するイオン風の挙動は, 挙動の一 瞬を示すシュリーレン写真だけでは不明なので，モデ

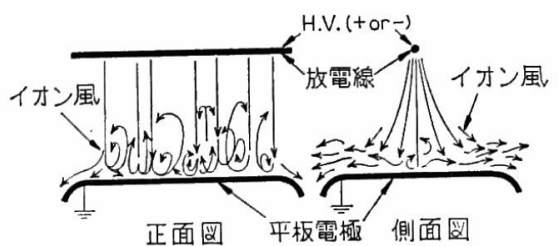

第 6 図 線対平板電極におけるイオンの挙動

Fig. 6. Aspect of ionic wind for wire vs. plate electrode. 
ル図を作成すると第 6 図のようである。この図は第 5 図の (b), (c ) の場合ならびに同一条件下の側面から のイオン風の挙動を観察して、コロナ放電がじゅうぶ ん行なわれている場合について作成したもので，側面 図については第 11 図屯参考とした。図中のコロナ輝 点の発生之消滅に基づく, 時々刻々と変化する小さな うず流現象は側面図から判断して，放電線直下のみに 発生するようである。

$\langle 3 \cdot 2\rangle$ 針電極対平板電極の場合のイオン風針 電極 3 本を用いてイオン風の干渉の様子について観察 を試みる。電界は第 2 図の電極 $(a)-(c)$ 組合せで 構成し, 加熱電流 $I_{h}=5 \mathrm{~A}$ で針電極 1 本の発熱量は $66 \mathrm{~W}$ である。 $E=0 \mathrm{kV}, I_{h}=5 \mathrm{~A}$ における加熱線の 表面温度は約 $740^{\circ} \mathrm{C}$ である。 $E=20 \mathrm{kV}$ では, 構造の 関係から前節の場合のようにイオン風の冷却作用が顕 著でないため約 $700^{\circ} \mathrm{C}$ である。

第 7 図に針電極 3 本の場合の負性イオン風のシュリ ーレン写真を示す。(a)図は初期コロナの段階でイオ ン風が発生しているが風圧が小でうず流現象は生じて いない。（b）図はコロナ放電が盛んになり負性イオン 風の挙動か顕著になった状態で, 両側のイオン風はい

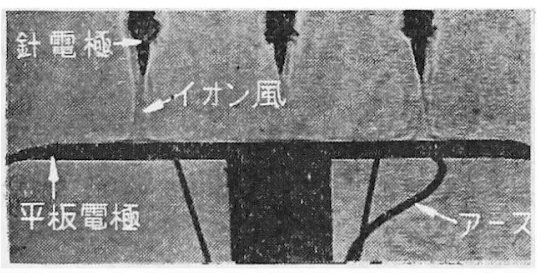

(a) $E=4.5 \mathrm{kV}, I_{c}=2.4 \mu \mathrm{A}$

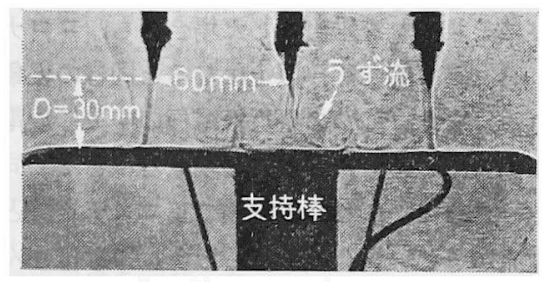

(b) $E=14.0 \mathrm{kV}, I_{c}=57.2 \mu \mathrm{A}$

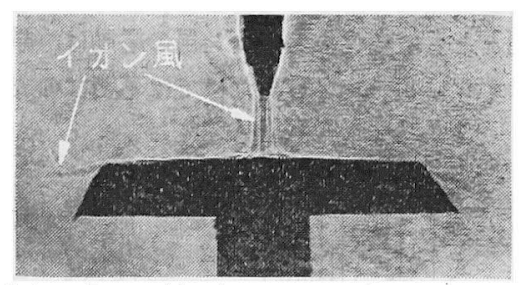

(c) $E=14,0 \mathrm{kV}, I_{c}=57.2 \mu \mathrm{A}[(\mathrm{b})$ 図の側面図]

第 7 図 3 本の針対平板電極に扔ける負性 イオン風のシュリーレン写真

Fig. 7. Schlieren photographs of negative ionic wind for three needles vs. plate electrode.

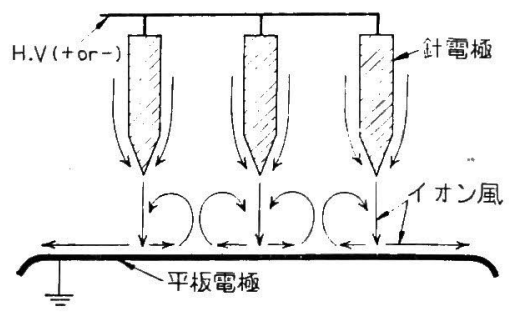

第 8 図3本の針対平板電極におけるイオ ン風の挙動

Fig. 8. Aspect of ionic wind for three needles vs. plate electrode.

ずれむ外側に向う圧力を受けている。( c) 図は (b)図 の状態を側面から観察したものであるが，イオン風の 干涉がないので針電極 1 本について行なったシュリー レン写真とほとんど同じ状態である。これらのてとか ら大きなうず流現象は前節と同様に 3 本の針電極を含 む同一平面内にコロナ輝点間の空間において生じてい る。

第 7 図（b)亿基ついてモデル図を作成すると第 8 図 のようになる。この図に示すようにコロナ輝点（針電 極先端) から発生したイオン風の主流は平板電極衞 突して，隣にコロナ輝点がない場合には平板電極面に 沿って流れ去るが，隣接してコロナ輝点がある場合に は，扔互がいのイオン風が電極面上で衝突して盛り上 り，上昇気流になって大きなうず流現象を生じる。

$\langle 3 \cdot 1\rangle$ 節ならびに〈3.2〉節から次の点が推測される。

（1）コロナ輝点が放電線に多数発生する電界では イオン風の相互干涉によって小さなうず流現象が放電 線直下の平板電極近傍に多〈発生する。このととは 3 本並列針電極を用いた実験において一そう顕著住観察 される。

（2） 3 本の並列針電極の実験結果からさらに，2 本以上の放電線が並列汇設けられている装置において は, 各放電線間の空間にむ大きなうず流現象が生じる と考えられる。

（3）コロナ輝点の不定常によって，前述の小さな うず流現象はその発生場所と現象が時々刻々之変化す る。しかし，両電極間に発生する大きなうず流現象は 発生する場所は変らないが, 状態がでくわずか変化す る。

〈3.3〉 円筒形集じん器のイオン風 第 2 図の電 極 $(\mathrm{b})$ - (d) を組合せた円筒形 EP においては，E-I。 放電特性が印加電圧の上昇に伴ない加熱電流 $I_{h}=5 \mathrm{~A}$ の特性が $I_{h}=0 \mathrm{~A}$ 特性にわずかに近つく傾向しか示 さない。このととは円筒内部でのイオン風による放電 線冷却効果がそれほど顕著でないことを示している。 


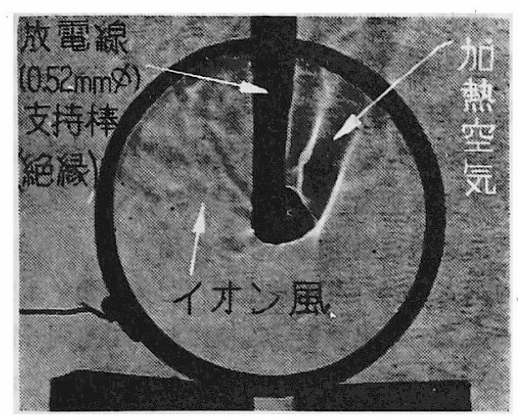

(a) $E=6.5 \mathrm{kV}, I_{c}=2.2 \mu \mathrm{A}$

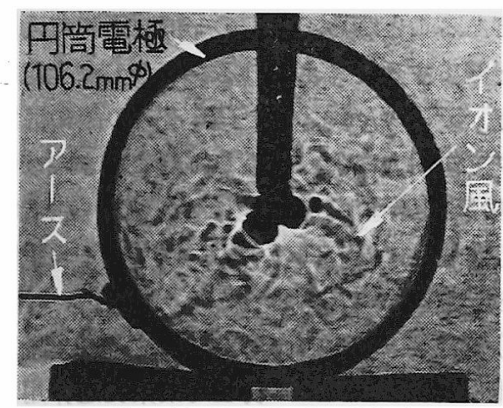

(b) $E=15.0 \mathrm{kV}, I_{c}=66.0 \mu \mathrm{A}$

第 9 図 円筒形電気集じん器における負性 イオン風のシュリーレン写真

Fig. 9. Schlieren photographs of negative ionic wind in cylindrical type electrostatic precipitator.

第 9 図に模擬円筒形 EP における負性イオン風のシ ニリーレン写真を示す。(a)図は初期コロナの段階 で，自然対流の気流が乱れているととが分る。（b)図 はコロナが活発になった段階でイオン風が放電線から 円筒電極に向って放射状汇吹いていることがうかがわ れる。内筒内部では放電線の全長にわたって生じてい るイオン風が重なり合って観察されている。放電線か ら放射状㐸いたイオン風は，コロナ輝点の不定常性 から放電極近傍で小さな複雑なうず流現象を発生して いると察知される。また，放電線の振動によるコロナ 輝点の大きな変化によっても, イオン風は円筒電極表 面上に到達し，あるいはその過程において，互いに衝 突して相互に干渉を起こして複雑な小さなうず流現象 （前節の二つの針電極間のうず流現象に比較して）を 生ずるであろうと考えられる。

\section{4. イオン風速分布}

シュリーレン法による定性的観察結果で, さらに定 量的に考察するため線電極には第 2 図（a)を用い平板 電極には (b)図と外形寸法が同じ金網電極を用い，金 網電極裏において風速測定を行なった。ての電極構成 において平板形 $\mathrm{EP}$ とはイオン風の挙動が異なるがイ
オン風速測定のつごうと，実用される金網電極につい ても，一応考察する必要からこの電極構成を採用し た。

サーミスタ風速計の検出素子（直径 $1.5 \mathrm{~mm}$ ) は線 電極正面位置を $X=0 \mathrm{~mm}$ として線電極と直角方向に 移動させる。また，風速測定は線電極に対し金網電極 の裹側面から距離 2 7 $\mathrm{mm}$ の管囲では測定にほとん ど差がないので $5 \mathrm{~mm}$ において行なった。金網は目開 き $1.00 \times 1.06 \sim 2.93 \times 3.07 \mathrm{~mm}$, 線径 $0.74 \sim 1.14 \mathrm{~mm}$ を使用したが，この筑囲では $E-I_{c}$ 特性は第 4 図とほ とんど差がない。

第 10 図纪示す負性イオン風のシュリーレン写真に おいて，うず流現象がかすかにうかがわ机るが，目開 きがあらくなるほどこの現象は減少した。第 10 図と 同一条件で印加電圧 $E$ パラメータの負性イオン風速 分布を第 11 図任示す。( $a$ )図より (d) 図の特性のほ うが広がりが大きいのは， $I_{h}=5 \mathrm{~A}$ のとき気体温度が 高いので, 粘性作用が大きい(11)ととに原因すると考え られる。また，正性イオン風速分布は負性イオン風速 分布に比較して，大きな相異は認められなかった。第 10 図(第 6 図参照) は第 11 図のイオン風速分布の全 貌を示すわけではなく，放電線を含む金網電極に対し て直角な面（すこし厚みがある）におけるイオン風の 挙動を示していることになる。

第 11 図の負性イオン風速分布と第 4 図の放電特性 から計算して，イオン風として移動する分子はほとん ど中性ガス分子でイオンはごくわずか（付録 I 参照） である。また，コロナ放電の電気エネルギーのうちわ

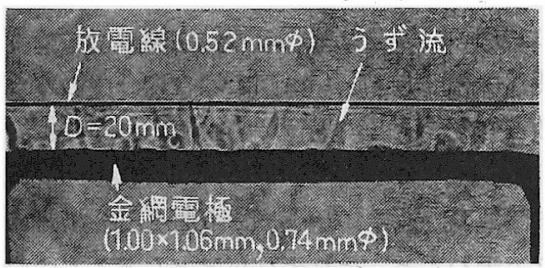

(a) $E=8.0 \mathrm{kV}, I_{c}=34.5 \mu \mathrm{A}$

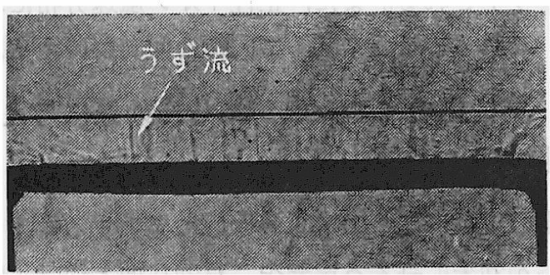

(b) $E=12.0 \mathrm{kV}, I_{c}=180_{\mu} \mathrm{A}$

第 10 図線対金網電極にお捄角性イオン 風のシュリーレン写真

Fig. 10. Schlieren photographs of negative ionic wind for wire vs. net electrode. 


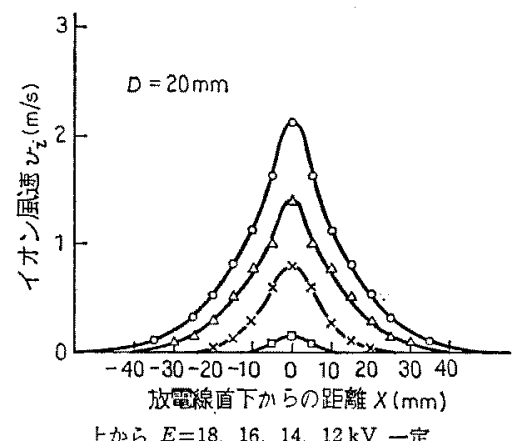

(a) 教電線加熱霆流 $I_{h}=0 \mathrm{~A}$

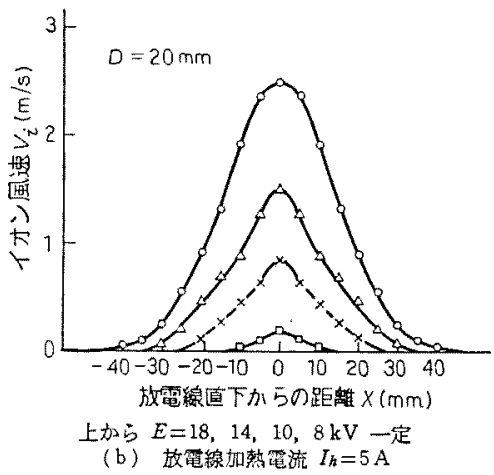

第 11 圀線対網電極における真性イオン風 速の分布

Fig. 11. Distribution of negative ionic wind velocity for wire vs. net electrode.

ずか $10^{-2}$ オーダのパーセント(付録II参照) が風の運 動エネルギーになったにすぎない。すなわち，このコ ロナ放電装置を送風装置として考元る上非常化効率の 悪い装置というととになる。

第 11 図(a)のそれぞれの特性曲線は二つのガウス 分布関数の和として，(b)図の場合は一つのガウス分 布関数として表わした場合，実験值とかなりよい一致 (付録亚参照)が得ら杭。さらに，てれら三つのガウ ス分布関数の分散 $\sigma^{2}$ を縦軸に印加電玨を横軸にして グラフで表わすと，それぞれがほ上んど3本の直線上 にプロットさ机る。また，正性イオン風速分布におい ても，と㣗らのてとに関して同様の傾向がいえる。

\section{EP 内のイオン風が集しん効果に与える 影䇾について}

以上の実験任基ついて，EP 内に発生するイオン風 が集じん効果に与える影響を，有効な面と逆効果的な 面とについて考察する。

I．有効な面

（1）ダストを集じん電極に駆動する集じん速度増 加作用
（2）集じん速度增加と気流じょう乱による柆子の 物理的凝集促進作用

II. 逆効果的な面

（1）再飛散現象と類似な現象の発生作用

(2) 放電線肥大現象を誘発する作用

(3) 放䉓楾振動を誘発する作用

I（1)の考察 第 1 章に述べた条件のイオン風速

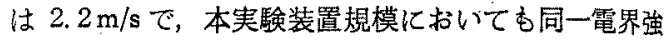
度で $0.92 \mathrm{~m} / \mathrm{s}$ 第 11 図(b)より〕となる。これらは 笔極直下の最大風速であり，加つ平板電極でなくて金 網電極であることから，EP の一般粒子に与える速度 はもっと減少すると考えられる。しかし，上記と同一 電界強度 $(5.7 \mathrm{kV} / \mathrm{cm})$ で粒子径 $2 \mu$ の飽和带電粒子 がクーロン作用力によって集じん極に引きつけられる 速度は $0.32 \mathrm{~m} / \mathrm{s}^{(12)}$ である。したがって, 帯電粒子の 集じん力向速度に同方向のイオン風に上る粒子駆動作 用が大きく影響すると考えられる。

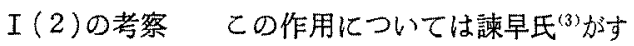
でに考察している。ここで物理的㠜集促進作用はイ才 ン風による駆動効果が垃子径によって異なるととと気 流かく乱によって，空間におりる粒子相互の衝突によ るものと，電極表面上におけるサイクロン的な作用に よるものの二つに分けられる。てれらは電気的疑集作 用による集じん効果と同じ効果をむたらすと考える。

III（1）の考察ＥP の処理ガス速度は再形散現象 の発生限界加ら一般的に $2 \mathrm{~m} / \mathrm{s}$ 以下(7)が採用されてい るととと前述のイオン風速から考虑して，処理ガス風 速とイオン風速の合成されたところには再飛散現象が 生じやすいと考えられる。さらに再飛散した粒子はう ず流作用によって，放電極方向へもおしやられるであ ろうとともじゅうぶ考えら机る。

III (2)の考察 $\langle 3 \cdot 2\rangle$ 節で 2 種類のうず流現象が 発生すると述べたが，これらのうず流作用によって放 電電極の方向へ駆動される粒子が少なくないと考えら れる。したがって，放電電極近傍の誘電作用力 ${ }^{(6)}$ が大 きく墈く領域に柆子が飛び込んでくることになるので 放電線肥大現象を促進する原因を成す。

III（3)の考察カルマンうずによる放電線振動加 発が知られており，前述の小さなうず流現象とコロナ 輝点加ら発生するイオン風によって，放電線の共振振 動が放電線の状態によっては誘発されうる。

\section{6. むすび}

以上の実験ならびに考察の結果を要約すると，次の ようである。

（1）正性コロナ放電ならび負性コロナ放電伅伴 
なって発生するイオン風を区別して，正性イオン風な らびに負性イオン風上呼ふことにする。(筆者提案)

（2）本実験におりる種々電極構成において，コロ ナ放電が安定した同一電流值のもとでは正性イオン風 ならびに負性イオン風の挙動はシュリーレン法によ る観察のが゙りではほとんど同一の現像である。

(3) 平板形 EP で放電線が 2 本以上ある場合, 放 電線直下の空間にコロナ輝点のばらつきによる小さな 多数のうず流が発生し，二つの放電線間に二つのイオ ン風衙突による大きなうず流（3本並列針電極実験よ り推測）加発生すると考えられる。前者は発生場所上 見象が時々刻々上変化するが, 後者はほ上んど变化し ない。

（4）円筒形EPでもうず流現象上思われる学動が 観察された。小さな複雑なうず流胃象が放電線から円 筒電極に至る空間に発生していると考えられる。

（5）平板形 $\mathrm{EP}$ の負性イオン風速分布から計算す ると，風として移動する分子はほとんど中性分子でイ オンはでくわずかである。また，コロナ放電による電 気エネルギーに対して風の運動エネルギーは $10^{-2}$ 才 ーダのパーセントであって効率としては非常に小さな 值である。

（6）EP 内のイオン風の存在は粒子の集じん過程 亿括いて，有効な面として粒子速度增加作用ならびに 物理的凝集作用，また逆效果的な面として放電線振 動, 再飛散現象ならびに放電線肥大現象を促進するむ のと考えられる。

本報告をまこめるにあたり終始懇切なご指薄老いた だいた西日本工業大学橋本清隆教授ならびにシュリ ーレン装置使用について便宜をはかっていただいた日 立製作所諫早典夫博士のご厚意に㳭く樈意を表する。 また，実験その他でじ援助いただいた西日本工業大学 川䗁元之講師, 本学陶山俊道助手, 池田隆技官に感 謝する。

(昭和 47 年 8 月 30 日受付，同 47 年 12 月 4 日再受付)

\section{文献}

（1）本多：気体放電琴臬 96 (昭 46)

(2) W. Deutsch: Ann. Phys. 476, 729 (1925)

(3) 湅早: 学位諭文 (恵京大学) (昭 36-12)

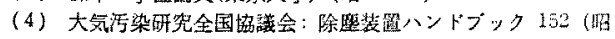
$36-12)$

(5) J. White: Electrostatic Precipitation 235 (1963)

(6) 足立: 電学誌 90,710 (略 45-4)

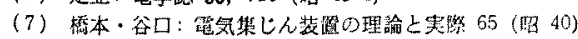

(8) 電気学会: 放笔現象 65 (圆 41)

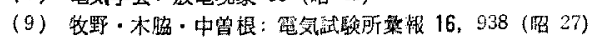

(10) 本多: 気体放籍現象 83 (略 46)

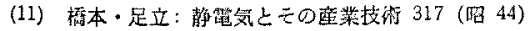

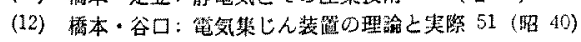

(13) 褔田：応用統計入阴 76 (昭 46)

\section{付 録}

I. 風に含まれるイオンと中性分子の比 イオン 風として移動するガス中に合まれるイオンの個数 $n$ 杜 $e$ を電子の電荷 $(\mathrm{C}), Q$ を風量 $\left(\mathrm{cm}^{3} / \mathrm{s}\right), I_{c}$ をての上 きのコロナ電流 $(\mathrm{A})$ とすると，次式で表わされる。

$$
n=\frac{I_{c}}{e Q}\left(\text { 個 } / \mathrm{cm}^{3}\right)
$$

ここで，風量 $Q$ は第 11 图(a)における $E=14 \mathrm{kV}$ $\left(I_{c}=74 \mu \mathrm{A}\right)$ のインン風速分布曲線の面積 $S$ (区分求積 法で求めると $\left.124.8 \mathrm{~cm}^{2} / \mathrm{s}\right)$ 上放電線有効長 $l(21 \mathrm{~cm})$ の皘で表わされる。

$$
Q=S l=2.62 \times 10^{3}\left(\mathrm{~cm}^{3} / \mathrm{s}\right) \text {. }
$$

$I_{c}$ 上 $e$ の値ならび们(付 2 )式を(付 1 ) 式代入する $\varepsilon$

$$
\begin{aligned}
n & =\frac{I_{c}}{e Q}=\frac{74 \times 10^{-6}}{1.602 \times 10^{-19} \times 2.62 \times 10^{3}} \\
& =1.76 \times 10^{11}\left(\text { 個 } / \mathrm{cm}^{3}\right)
\end{aligned}
$$

となる。

標準状態に沶汀気体分子密度 $2.67 \times 10^{19}$ (㧽 $/ \mathrm{cm}^{3}$ ) に比較すると 8 けたも異なる。したがって，電界内に おけるイオンの移動によって誘起されたイオン風はは 上んど中性ガス分子の移動棌るるのである。

II. イオン風の運動エネルギーと電気エネルギーの 比付録 I 上同一条件の風速分布曲線を $\Delta X=2 \mathrm{~mm}$ 上して区分し，古る区分域に书けるイオン風の軍動エ ネルギー $w_{i j}$ 求的て，その総和を求的る上全体の イオン風の運勳エネルギー Wiになる。

$$
\begin{aligned}
W_{i} & =\sum_{j} w_{i j}=\frac{1}{2} \sum_{j} \rho V_{j} v_{i j}{ }^{2} \\
& =0.47 \times 10^{-3}(\mathrm{~W}) \quad \ldots . .
\end{aligned}
$$

ただし， $\rho:$ 空気の密度 $1.293 \mathrm{~kg} / \mathrm{m}^{3}, V_{j}:$ ある 区分域の風量， $V_{i j}$ ：ある区分域の平均イ才ン風 速である。一方電気エネルギーW。は棸件より

$$
W_{e}=E I_{c}=14 \times 10^{3} \times 76 \times 10^{-6}
$$

$$
=1.04(\mathrm{~W})
$$

（付 3 )式上（付 4 )式の此吉求方る

$$
\frac{W_{i}}{W_{e}} \times 100=\frac{0.47 \times 10^{-3}}{1.04} \times 100=0.045
$$

となる。したがって，コロナ故電による電気エホルギ 一のはとんよ゙は，䓡，音。光なよ゙によって発散し， 10-2オーダのパーセントのエネルギーがイオン風のエ ネルギーになったにすぎない。

III. イオン風速分布の関数表示 第 11 図の1 オン風速分布をガウス分布関数 ${ }^{(13)}$ で表吅すことにす る。（a ）図の印加電圧 $E=18 \mathrm{kV}$ に拈ける分布曲線は 
次のように二つのガウス分有関数の和として表わされ る。

$$
\begin{aligned}
f(X) & =f_{1}(X)+f_{2}(X) \\
& =1.22 \exp \left\{-\frac{X^{2}}{434}\right\}+0.88 \exp \left\{-\frac{X^{2}}{54.3}\right\}
\end{aligned}
$$

(b)図の同一条件の分布関数は，次のように一つのガ ウス分布関数で表わされる。

$$
f_{3}(X)=2.47 \exp \left\{-\frac{X^{2}}{393}\right\}
$$

印加電㞋 $E$ を変化させた場合，(a)図は二つの式 の和で，また（b)因は一つの式で近似的（澡差は数 $\%$ 以下）に表わされる。このととは前者は俊鋭な山 形を示し，後者は加熱電流による気流粘性增加のため やや鈚った山形を示す。

上記三つの関数 $f_{1}(X), f_{2}(X), f_{3}(X)$ における 母標準偏差を $\sigma_{1}, \sigma_{2}, \sigma_{3}$ とすると， $\sigma_{i}{ }^{2}$ 之印加笔压: $E$ の間にはこれら三つのこう配は異なるが，概略直線的 関保が得られた。このことは $E$ が定まれば近似的に 風速分布加簡単に求めら机ることを示している。 